\title{
Hubungan Antara Resistensi Insulin dan Tekanan Darah pada Anak Obese
}

\author{
Adrian Umboh, Jully Kasie, Johannes Edwin
}

Latar belakang. Obesitas merupakan masalah yang penting dengan prevalensi yang cenderung meningkat serta berhubungan dengan penyakit metabolik antara lain hipertensi dan resistensi insulin. Mekanisme terjadinya hipertensi pada obesitas sangat kompleks, salah faktor yang berperan adalah adanya resistensi insulin.

Tujuan. Untuk mengetahui hubungan antara resistensi insulin dan tekanan darah pada anak obese.

Metoda. Penelitian bersifat analitik observasional dengan desain cross sectional yang dilakukan pada anak SMP kelas 1 hingga kelas 3 berusia antara 11 hingga 15 tahun yang memiliki IMT > persentil ke-95 di Wenang Kota, Kotamadya Manado pada bulan Juli hingga Agustus 2004. Pemeriksaan basal insulin darah puasa dengan menggunakan metode radioimmuno assay (RIA). Tekanan darah diukur 2 kali selama 2 hari berturut dan hasil merupakan rerata ke-2 nilai tersebut. Definisi pre-hipertensi bila tekanan darah sistolik $=120 \mathrm{mmHg}$ dan tekanan darah diastolik $=80 \mathrm{mmHg}$ serta resistensi insulin bila insulin darah puasa $=18 \mu \mathrm{U} / \mathrm{mL}$.

Hasil. Diantara 72 anak diteliti, didapatkan hasil 24 anak $(33,33 \%)$ menderita resistensi insulin terdiri dari 13 anak laki-laki $(54,17 \%)$ dan 11 anak perempuan (45,83\%). Anak obese yang disertai resistensi insulin memiliki nilai median tekanan darah sistolik lebih tinggi secara bermakna dibandingkan tanpa resistensi insulin $(\mathrm{p}=0,006)$. Dijumpai $86,11 \%$ anak obese memiliki tekanan darah sistolik $=120 \mathrm{mmHg}$ dan $93,06 \%$ tekanan darah diastolik $=80 \mathrm{mmHg}$. Terdapat hubungan antara insulin darah dan tekanan darah sistolik $\left(r_{s}=0,297, p=0,018\right)$ dan ada hubungan antara insulin darah dan tekanan darah diastolik $\left(r_{s}=0,298, p=0,011\right)$.

Kesimpulan. Sebagian besar anak obese menderita pre-hipertensi, namun hanya ditemukan korelasi linier yang sangat lemah antara resistensi insulin dan tekanan darah.

Kata kunci: obesitas, resistensi, insulin, hipertensi

\footnotetext{
Alamat korespondensi:

Dr. Adrian Umboh, Sp.A(K), Dr. Jully Kasie, Sp.A,

Dr. Johannes Edwin, Sp.A.

Bagian Ilmu Kesehatan Anak FK. Unsrat/RSU Prof.Dr. R.D. Kandou, Manado.

Telepon: 0431-821652, Fax:0431-859091, E-mail: ikarsup@telkom.net
}

O besitas merupakan masalah kesehatan penting dan semakin meningkat pada anak maupun remaja. Akibat obesitas yang dahulu hanya merupakan penyakit yang dijumpai pada orang dewasa, kini dapat dijumpai pada anak-anak. ${ }^{1}$ Akibat obesitas antara lain hipertensi, diabetes mellitus tipe 2, dislipidemia, hipertrofi ventrikel kiri, steatohepatitis non alkoholis, masalah sosial serta psikologis. ${ }^{1,2}$ 
Hubungan antara obesitas dan hipertensi telah lama diketahui dan telah banyak dilaporkan oleh banyak peneliti. Namun mekanisme yang pasti bagaimana terjadinya hipertensi akibat obesitas hingga saat ini belum jelas. Sebagian besar peneliti menitikberatkan patofisiologi tersebut pada 3 hal utama yaitu adanya gangguan sistem autonom, resistensi insulin serta abnormalitas struktur dan fungsi pembuluh darah. Ketiga hal tersebut dapat saling mempengaruhi satu dengan lainnya. ${ }^{1-6}$

Resistensi insulin diduga merupakan manifestasi awal dari terjadinya sindrom metabolik; yaitu suatu kumpulan faktor risiko terjadinya penyakit kardiovaskular seperti hipertrigliserida, hiperinsulinemia, hiperglikemia, serta hipertensi. ${ }^{4}$

\section{Metoda}

Penelitian ini bersifat deskriptif dan analitik observational dengan menggunakan desain penelitian cross sectional. Penelitian dilakukan pada bulan Juli hingga Agustus 2004 pada anak Sekolah Menengah Pertama di daerah Wenang Kotamadya Manado dan pengambilan sampel dilakukan secara stratified random sampling pada anak kelas 1 hingga kelas 3, usia antara 11 hingga 15 tahun yang memiliki indeks masa tubuh (IMT) lebih dari persentil ke-95. Selanjutnya dipilih 72 anak yang memenuhi kriteria tersebut. Pada subyek dilakukan pemeriksaan kadar insulin darah puasa dan pengukuran tekanan darah. Subyek dikeluarkan dari penelitian apabila menderita penyakit ginjal, mengkonsumsi obat anti hipertensi dan minum kopi.

Definisi resistensi insulin apabila kadar insulin puasa dalam darah $>18 \mu \mathrm{U} / \mathrm{mL}$. Sedangkan prehipertensi apabila tekanan darah sistolik $=120 \mathrm{mmHg}$ dan tekanan darah diastolik $=80 \mathrm{mmHg}$. Tekanan darah diukur pada posisi duduk setelah beristirahat selama 15 menit pada lengan kanan, dan dilakukan pagi hari selama 2 hari berturut-turut dan hasil pengukuran berdasarkan rerata tekanan darah pada kedua pengukuran tersebut. Tekanan darah sistolik berdasarkan bunyi Korotkoff pertama dan tekanan darah diastolik berdasarkan bunyi Korotkoff kelima. Sampel darah diambil pada pagi hari dalam keadaan puasa. Pemeriksaan basal insulin darah dengan menggunakan metode Radioimmuno Assay (RIA).

Uji statistik untuk mengetahui perbedaan tekanan darah pada kelompok resistensi insulin dan tanpa resistensi insulin dengan menggunakan uji Mann Whitney U, sedangkan untuk mengetahui hubungan antara tekanan darah dan kadar insulin plasma dengan menggunakan koefisien korelasi Spearman.

\section{Hasil penelitian}

Pada Tabel 1 tertera 72 anak menderita obesitas yang terdiri dari 40 anak laki-laki $(55,5 \%)$ dan 32 anak perempuan (44,5\%). Dua puluh empat anak dari 72 anak obese memiliki kadar insulin $>18 \mu \mathrm{U} / \mathrm{mL}$ yang terdiri dari 13 anak laki-laki (54,17\%) dan 11 anak perempuan $(45,83 \%)$. Nilai median tekanan darah sistolik anak perempuan $(130 \mathrm{mmHg})$ lebih tinggi dibandingkan anak laki-laki (120 $\mathrm{mmHg}$ ) namun setelah dilakukan uji statistik tidak didapatkan adanya perbedaan yang bermakna $(\mathrm{p}=0,157)$. Sedangkan nilai median tekanan darah diastolik pada anak perempuan dan laki-laki tidak berbeda.

Didapatkan 62 anak (86,11\%) memiliki tekanan darah sistolik sama atau lebih besar dari $120 \mathrm{mmHg}$ dan 67 anak (93,06\%) memiliki tekanan darah diastolik sama atau lebih besar dari $80 \mathrm{mmHg}$. Nilai median tekanan darah sistolik pada anak yang menderita resistensi insulin $(130 \mathrm{mmHg})$ lebih tinggi secara bermakna dibandingkan anak tanpa resistensi insulin $(120 \mathrm{mmHg})$ dengan nilai $\mathrm{p}=0,006$. Sedangkan tekanan darah diastolik pada kedua kelompok tidak berbeda.

Gambar 1 menunjukkan semakin tinggi kadar insulin darah semakin tinggi pula tekanan darah sistolik. Dari hasil analisis dengan menggunakan koefisien korelasi Spearman rank (rho) diperoleh $r_{s}=0,279$ dengan $p=0,018$. Hal ini menunjukkan adanya korelasi yang sangat lemah antara kadar insulin dan tekanan darah sistolik $(\mathrm{p}<0,05)$.

Tabel 1. Distribusi obesitas, resistensi insulin dan tekanan darah berdasarkan jenis kelamin

\begin{tabular}{|c|c|c|c|}
\hline Variabel & Laki-Laki & & Perempuan \\
\hline Obesitas n (\%) & $40(55,5)$ & & $32(44,5)$ \\
\hline Resistensi insulin $\mathrm{n}(\%)$ & $13(54,17)$ & & $11(45,83)$ \\
\hline \multicolumn{4}{|c|}{ Median tekanan darah $(\mathrm{mm} \mathrm{Hg})$} \\
\hline - Sistolik & 120 & 130 & $\mathrm{p}=0,157$ \\
\hline - Diastolik & 80 & 80 & \\
\hline
\end{tabular}




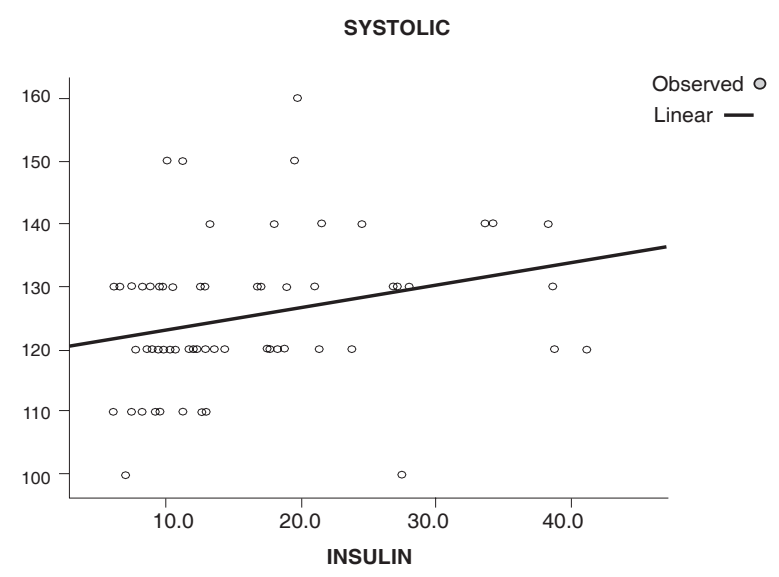

Gambar 1. Hubungan antara kadar insulin darah dan tekanan darah sistolik.

Gambar 2 menunjukkan hubungan yang sangat lemah antara kadar insulin darah dan tekanan darah diastolik dengan $r_{s}=0,298$ dengan $p=0,011$.

\section{Diskusi}

Penelitian ini dilakukan pada 72 anak SMP yang menderita obesitas, terdiri dari 40 anak laki-laki $(55,55 \%)$ dan 32 anak perempuan $(44,45 \%)$. Resistensi insulin pada penelitian ini didapatkan sebanyak 24 anak $(33,33 \%)$ terdiri dari 13 anak lakilaki $(54,17 \%)$ dan 11 anak perempuan (45,83\%). Prevalensi resistensi insulin pada anak obese ini tidak berbeda jauh dengan yang dilaporkan oleh Tresaco dan kawan-kawan, ${ }^{7}$ yang mendapatkan resistensi insulin pada 35,8\% anak obese. Prevalensi resistensi insulin meningkat dengan meningkatnya umur, obesitas, riwayat keluarga, aktivitas fisik dan IMT. ${ }^{8}$ Dibandingkan laki-laki, anak perempuan memiliki resistensi insulin yang lebih besar pada usia perkembangan seksual yang sama meskipun belum jelas apakah perbedaan ini disebabkan faktor-faktor khusus atau karena kandungan lemak tubuh yang lebih banyak pada perempuan. ${ }^{9}$ Salbe dan kawan-kawan ${ }^{10}$ dalam penelitiannya yang dilakukan pada kelompok umur 5 hingga 10 tahun mendapatkan bahwa konsentrasi insulin dan gula darah puasa sangat berhubungan dengan persentasi lemak tubuh dan berat badan serta tidak berhubungan dengan jenis kelamin. Perbedaan hasil dengan penelitian ini kemungkinan

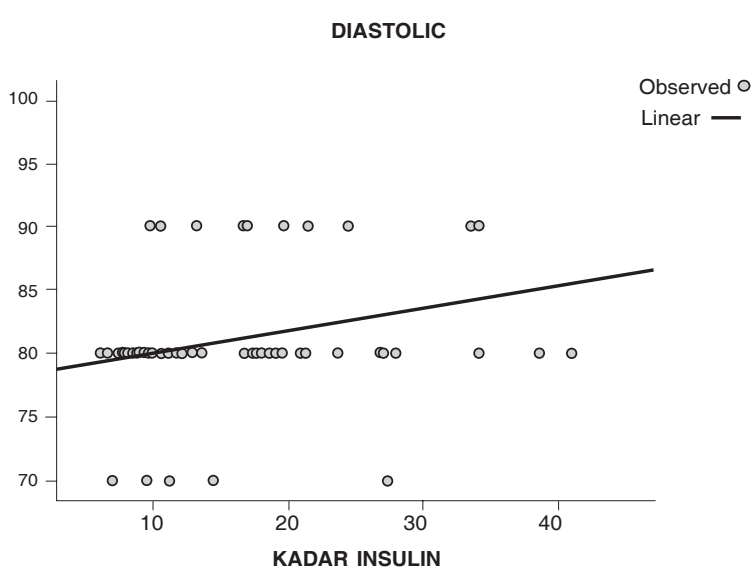

Gambar 2. Hubungan antara kadar insulin darah dan tekanan darah diastolik.

disebabkan karena jumlah sampel anak laki-laki pada penelitian ini lebih besar daripada anak perempuan, namun faktor-faktor yang lainnya belum dapat disingkirkan dan memerlukan penelitian lebih lanjut.

Tekanan darah sistolik pre-hipertensi didapatkan pada 62 anak $(86,11 \%)$ serta tekanan darah diastolik pre-hipertensi didapatkan pada 67 anak (93,06\%). Nilai median tekanan darah sistolik anak perempuan $130 \mathrm{mmHg}$ lebih tinggi daripada anak laki-laki dengan nilai $120 \mathrm{mmHg}$, namun tidak didapatkan adanya perbedaan bermakna $(p=0,157)$. Hubungan antara obesitas dan hipertensi pada anak dan remaja telah dilaporkan oleh beberapa penelitian pada kelompok etnis dan ras dimana tekanan darah anak obese lebih tinggi daripada non obese. ${ }^{11}$ Sorof dan kawan-kawan, ${ }^{1}$ melaporkan risiko terjadinya hipertensi pada kelompok obese tiga kali lebih besar dibandingkan dengan kelompok non obese. Freedmann dan kawan-kawan, ${ }^{12}$ pada penelitian Bogalosa Heart Study mendapatkan peningkatan kenaikan tekanan darah sistolik 2,4 kali pada anak yang menderita overweight dibandingkan kelompok gizi baik. Hal yang sama dilaporkan oleh Rosner dan kawan-kawan, ${ }^{13}$ dari hasil delapan penelitian epidemiologi di Amerika Serikat didapatkan anak dengan IMT yang tinggi memiliki tekanan darah yang lebih tinggi pula. Manifestasi awal hipertensi pada obesitas diawali oleh terjadinya hipertensi sistolik tanpa disertai hipertensi diastolik (isolated systolic hypertension). Sorof dan kawan-kawan, ${ }^{1}$ melaporkan pengukuran tekanan darah pada remaja yang menderita obesitas ditemukan sebanyak 94\% memiliki 
Sari Pediatri, Vol. 8, No. 4, Maret 2007

hipertensi sistolik. Izzo dan kawan-kawan, ${ }^{14}$ dalam penelitiannnya pada kelompok remaja di Amerika mendapatkan bahwa hipertensi sistolik tanpa hipertensi diastolik merupakan faktor resiko terjadinya morbiditas dan mortalitas kardiovaskular pada masa dewasa kelak .

Penelitian ini mendapatkan pula bahwa tekanan darah sistolik pada kelompok dengan resistensi insulin lebih tinggi secara bermakna dibandingkan tanpa resistensi insulin $(\mathrm{p}=0,006)$, namun hal ini tidak dijumpai pada tekanan darah diastolik. Mekanisme terjadinya hipertensi pada obesitas belum diketahui secara pasti, namun resistensi insulin merupakan salah satu faktor yang berperan dalam proses tersebut. Resistensi insulin diduga berperan dalam terjadinya sindrom metabolik yang dihubungkan dengan penyakitpenyakit kardiovaskular. ${ }^{1,2}$ Pada obesitas terjadi resistensi insulin dan gangguan fungsi endotel pembuluh darah yang selanjutnya menyebabkan terjadinya vasokonstriksi dan reabsorpsi natrium di ginjal yang mengakibatkan terjadinya hipertensi. ${ }^{2,6,11,15,16}$ Vanhala dan kawankawan, ${ }^{4}$ melaporkan risiko terjadinya sindrom metabolik tinggi pada kelompok yang mengalami obesitas sejak usia 7 tahun hingga usia remaja.

Uji korelasi yang dipakai pada penelitian ini mendapatkan adanya hubungan linier yang sangat lemah antara kadar insulin basal darah dan tekanan darah baik sistolik maupun diastolik. Hubungan antara resistensi insulin dan hipertensi telah banyak dilaporkan sebelumnya. ${ }^{15,16} \mathrm{Hal}$ serupa juga dilaporkan oleh Rocchini dan kawan-kawan ${ }^{11}$, yang mendapatkan adanya penurunan berat badan yang berhubungan dengan penurunan kadar serum insulin dan tekanan darah.

Kesimpulan penelitian ini, sebagian besar anak obese menderita pre-hipertensi, terdapat korelasi linier yang sangat lemah antara kadar insulin dan tekanan darah serta resistensi insulin mempengaruhi peningkatan tekanan darah sistolik pada anak obese. Kelemahan penelitian ini bersifat cross sectional dan faktor lain yang berperan dalam terjadinya hipertensi akibat resistensi insulin tidak diteliti. Maka perlu dilakukan penelitian longitudinal dan multisenter mengenai peranan resistensi insulin dalam terjadinya hipertensi mengingat resiko morbiditas dan mortalitas pada usia dewasa dapat dicegah dengan melakukan intervensi dini pada kelompok anak obese khususnya dengan resistensi insulin.

\section{Daftar Pustaka.}

1. Sorof J, Daniels S. Obesity hypertension in children. A problem of epidemic proportions. Hypertension 2000;40:441-7.

2. Montani JP, Antic V, Yang Z. Pathway from obesity to hypertension: From the perspective of a vicious triangle. Int J of Obesity 2002;Suppl 26:S28-38.

3. Kroke A, Bergmann M, Boeing H. Obesity, body fat distribution and body build: Their relation to blood pressure and prevalence of hypertension. Int J of Obesity 1998;22:1062-70.

4. Vanhala MJ, Vanhala PT, Takala MD. Relative weight gain and obesity as a predict metabolic syndrome as an adult. Int J of Obesity 1999;23:656-9.

5. Engeli S, Sharma AM. Emerging concepts in the pathophysiology and treatment of obesity associated hypertension. Curr Opin Cardiol 2002;17:355-9.

6. Kolanowski J. Obesity and hypertension: from pathophysiology to treatment. Int J of Obesity 1999;Suppl 23:S42-6.

7. Tresaco B, Bueno G, Moreno LA. Insulin resistance and impaired glucose tolerance in obese children and adolescents. J Physiol Biochem 2003;59:217-23.

8. Sung EJ, Sunwoo, Kim SW. Obesity as a risk factor for non-insulin dependent diabetes mellitus in Korea. J Korean Med Sci 2001;16:391-6.

9. Goran MI, Ball GKC, Cruz ML. Obesity and risk of type 2 diabetes and cardiovascular disease in children and adolescents. J Clin Endocrinol Metab 2003; 88:1417-27.

10. Salbe AD, Weyer C, Ravussin E. Assesing risk factors for obesity between childhood and adolescence: Birth weight, childhood adiposity, parental obesity, insulin and leptin. Pediatrics 2002;110:299-306.

11. Rocchini AP, Katch V, Schork A, Kelch RP. Insulin and blood pressure during weight loss in obese adolescents. Hypertension 1987:10:267-73.

12. Freedman DS, Dietz WH, Srinivasan SR, Berenson GS. The relation of overweight to cardiovascular risk factors among children and adolescents: The Bogalosa Heart Study. Pediatrics 1999;103:1175-82.

13. Rosner B, Prineas R, Daniels SR. Blood pressure between black and whites in relation to body size among US children and adolescents. Am J Epidemiol 2000;151:1007-19.

14. Izzo JLJ, Levy D, Black HR. Impotance of systolic blood pressure in older Americans. Hypertension 2000; 35:1021-4. 
Sari Pediatri, Vol. 8, No. 4, Maret 2007

15. Manicardi V, Camellini L, Bellodi G. Evidence for an association of high blood pressure and hyperinsulinemia in obese man. J Cil Endocrinol Metab 1986;62:1302-4.

16. Rose HG, Yalow RS, Schweitzer P, Schwartz E. Insulin as a potensial factor influencing blood pressure in amputees.Hypertension 1986;8:793-800. 